\title{
Self-Identification of Ravil Bukharayev's Lyrical Subject (as seen in A Wreath of Wild-Growing Sonnets)
}

\author{
V.R. Amineva, L.N. Yuzmukhametova \\ Kazan (Volga Region) Federal University \\ 18, Kremlevskaya Str., Kazan, Russian Federation
}

The works by Ravil Bukharayev (1951-2012) - who created his poetic texts in Russian, Tatar, English, and Hungarian and was involved in the Tatar literature and culture - possess a special art and esthetic nature, which demands evidence-based and adequate esthetic assessment. An attempt to reveal the functioning features of this genre and strophe form is made for the first timein the modern Russianspeaking poetry on the material of $A$ Wreath of Wild - Growing Sonnets, a cycle of poems by R. Bukharayev. The methodical studying system of the works, which are created on a joint of cultures, thus embodying new forms of a "hybrid" identity, relies on the doctrine about the dialogical nature of art creativity and on the theory of a trans-level of culture developed in foreign and domestic literary criticism. The conclusion is drawn that the wreath of sonnets stops being a static form in R. Bukharayev's lyrics, and its genre semantics is formed only by its composite structure.

The art integrity of this genre and strophe system is created not only by a "chained" design of a wreath connecting the end and the beginning of all cyclic context in general, but also by a concentric principle of the main subject development. It is defined that the subjective architectonics of this sonnet cycle is formed by the relations of the lyrical hero and special-type supersubjects - personified images of foreign culture. The main ways of overcoming the border between "own" and "other" are described in the article as follows: to study Hungarian which performs a replaceable function and to study the works. They are allocated with mythological features and find one-to-one correspondences: nature and person, "own" and "other", silence and a word, lines of a sonnet and flowers in a bouquet. The received results are significant for understanding the art and esthetic nature of the "boundary" phenomena in the modern literary process.

Key words: Russian literature, hybrid identity, “own”, "other”, genre poetics, subject architectonics

\section{Introduction}

A specific place in the modern Russian literary process is held by the creative use of the Russian language by the authors of "another nationality", who creates on a joint of cultures and embodies the "boundary" of art consciousness. R. Bukharayev (19512012) - the poet in constant pursue of his true self, who painfully endured a phenomenon of the "hybrid" identity - regards creativity as the subject of interest: "As a stepson of the native language, / I live, I write, and I think in Russian!” [1. P. 12]. R. Bukharayev writes in the preface to one of his books: "Perhaps, or for certain, this exact hopeless longing for old language / that for some reason became alien, this persistent desire to understand / why the foreign is not the native, with all its undivulged force / allowed to write verses in absolutely foreign languages" [2. P. 10]. 
Bukharayev's personality and creativity drew attention of literary critics. V.Bondarenko describes the tragic fate of the "Russian poet with the Tatar blood", who wanders worldwide - from Austria to Hungary, from India to Germany, from Japan to England and masters a wide variety of languages, but harbors the lack of belonging and the feeling of uselessness: "...London did not change the poet, and it was necessary for recognition of his authenticity - far from his small and big homelands. He also moved away farther from both Russia and Tataria to understand himself" [3. P. 378]. M.I. Ibragimov describes the concept of "multiple identification" in relation to works of the poet (see the works cited [4. P. 43]). From the personal notes of L. Bukharayeva: "Silence and speech; quietness and cacophony; connectionbetween such different languages: R.Bukharayev was tested by a new Word daily, every hour of his life. He lived inside the Language as if in a life paradigm" [5].

The intense search of his true self and identity was reflected in four wreaths of sonnets: The Bug and the Toad (a Wreath for the Coat of Arms) (1993), The Call (a Wreath of Foggy Sonnets) (2000), A Wreath of Wild-Growing Sonnets (2000), Alms of the Native Language (a Wreath of Humid Smoke) (2000), written in Russian, English, Hungarian, and Tatar respectively; the last three cycles represent the author's translation into Russian.

In domestic and foreign literary criticism $[6 ; 7]$ the extensive scientific and critical literature, generalized and systematized in a number of modern works, is devoted to such genresas sonnet and sonnet cyclic units, in particular, "a wreath of sonnets". The attention of scholars is also drawn by the fixed features of a wreath of sonnets in the Russian poems [8]. This article features the unprecedented analysis of a sonnet cycle by R. Bukharayev and the realization of the cultural border phenomenon from its artistic and esthetic side.

Methods and materials. The theoretical and methodological basis of the conducted research is based on the works of domestic and foreign scholars [9-11] who constructs the transcultural model of art development, which assumes "cultural diversity and universality as property of one's personality, a state of belonging of an individual to many cultures" [12. P. 97]. The works which reveal the features of the subject organization in the lyrical works had impacted the concept of the research $[13 ; 14]$. The method of analysis of the works by R. Bukharayev is based on the recognition principles of the cyclic interconnection of the sonnets [7] established in literary criticism and in features of a wreath of sonnets in different national literatures [8].

\section{Results and Discussion}

The architectonics of the sonnet cycles The Bug and the Toad (a Wreath for the Coat of Arms) (1993) and Alms of the Native Language (Wreath of Humid Smoke) (2000) is set by the relation of the poet and vital, creative elements of the national languages - Russian (the language of the fatherland) and Tatar (native language), which appear in the subjective forms. The intension in each of languages is expressed by the two-voiced words of the lyrical hero turned to "you" (speeches) and deictic character.

In the sonnet cycle The Bug and the Toad (A Wreath for the Coat of Arms) silence became one of the ways to determine and understand the "I" concept: "Then silence comes which is the speech. / Set free, you are not the one who protects me, / let in silence of a lotus and Punjab" [1. P. 314]. 
The silence is followed by the creation of myths. "The speech of the fatherland" is allocated with the mythological lines. Its relation to "I" is developed dramatically. The conflict begins with two opposite intensions, one of which is unilateral, active, strongwilled, and powerful (women's), another is passive, undergoing, searching, and asking (men's). The role of the female elements of language in life of the hero is dual: "Softly you lay, and your cloth is expensive, / but you bite like Punjab temple snake..." [1. P. 312]. The Punjab temple snake, to which the language of the fatherland is compared, is a negative demiurge who symbolizes unity of honey and poison, tenderness and pain, spirituality and corporal food.

The definition of the "jealous woman", who "reached and jumped behind a hillock" [1. P. 312], enters a love subject. The love collision seen as "adultery" is recognized as a treason in three other languages and a gap with " $i t$ " - the language of the fatherland. In the relations with "it", the lyrical hero jumps from entreaty ("I honestly begged as maternal milk, / only hot pitch of your wonder-working harmony" [1. P. 312]) to a confession ("I confess in unity of soul and spirit, / in unity of a stone and goose / set free - the victim is small" [1. P. 313]) to a request ("...set free - the victim is small... Let in silence of a lotus and Punjab..." [1. P. 313-314]), which quickly becomes the requirement (“... start up my soul from fornication to work!" [1. P. 314]).

The rhetoric of silence and passionate nihilism, which corresponds with total selfrejection and understanding of his soul as the victim, is solved by the exit to another plan of life and overcoming of all pragmatic restrictions and active life creation: "I myself will verify and I will adjust again, / I know when it is time for me to live and when to die, / I will victimize myself by my work" [1. P. 314]. The energy turned upside-down to its original form. At this moment it is the catharsis - the feeling of equal rights for both "I" and God - and finding the purpose in oneself, in never-ending self-implementation: "I estimated myself to the last mortal melancholy, / to the fact that heart comes to an end and temple aches, / and bringing to the final outcome / the biography, and geography, and vanity of attempts, / summarized that from now on, and suddenly, / I already have to do something to myself and God" [1. P. 317].

Life transformation of a lyrical subject corresponds with this process. The hero of the sonnet cycle becomes the center of infinite world space: "I'm approaching my nomadic threshold / from a pre-dawn prayer, and in shreds of spring darkness / I see taking away, and from here the road / where "I"s are senseless and "we" shave no advantage [1. P. 317]. "The nomadic threshold" is a point of ontological intense, meaning not only transition, but also the changes that are the creation of new vision and understanding of oneself and the world. There is an idea of his true self as a lonely and free creator, deprived of vital support: "The speech of the fatherland - not delight to my trouble" [1. P. 317], but finding vertical orientation of a way and ability to symbolically generalize and find the markers of identity: "And coat of arms is as follows: the full moon - is a sort to hill, / and in Leo's and Unicorn places - / the Bug and the Toad are at the edges of a wreath" [1. P. 317]. The tragic experiences of the lyrical subject are removed via irony as one of the ways of emotional and valuable existence of the person in the world. The irony is implemented as a style-forming factor that finds its expression in the mixture of various styles - high and low, colloquial and literary — as a philosophical position of the author who is looking for an exit from his tragically hopeless life situation. 
In other plan, the problem of the lyrical hero's self-identification in Bukharayev's works is solved in the cycle The Call ( $A$ Wreath of Foggy Sonnets). The poet widely uses deixis ${ }^{1}$ as an art form, which specifics are in an autoreflective frontage. This wreath of sonnets is interesting in the terms of interaction between two types of the deixis - denying and negative ("everywhere anybody's, without place in the Universe" [1. P. 321]); "But I am not a mirage..." [1. P. 322]), and positive with approving ("as a column on the crossroads" [1. P. 321]; "I am pain, a doubt, the fear of all strange" [1. P. 323]; "that animal on the lookout" [1. P. 323]; "as the Venice lion" [1. P. 323]; "as a cloud over Giudecca's temples" [1. P. 327]). In the first case, the autonomination of the lyrical hero is developing through the understanding that it is false; in the second case, the counting of the essential signs and properties or comparison identification, in which one-to-one image correspondences are established between the comparative and existential plans.

The architectonics of this wreath, as well as of the previous one, is defined by the meeting and combination of two intensions - direct and return: the questioning, going from the lyrical subject, which is in a condition of intense expectation of a response from the outside and from the world answering with silence: "...and hearing an echo, so again / I listen attentively to bring the calm from the sea coast" [1. P. 320]. An exit in creative measurement of life transforms the reaction of the hero to the "silence" of the world: "... in a foggy veil / I lay a wreath, which branches, as the rivers, / run together in a sea stream..." [1. Pp. 327-328]. Laying a wreath from the branches of rivers creates avivid picture of the creative act, in which individual and personal beginning is absorbed by the natural and the mythological: "Venice closes her eyelids again, / appreciating the moment; a wreath or not a wreath, / the echo of these lines will be soaked by fogs" [1. P. 328]. The mythological semantics offer the prospect of rapprochement and harmonization of two different intensions and the prospects correlated to them. Laying a wreath gains a heroic character: the lyrical subject gives the world his creative energy, passes to the internal point of view of the city and nature, promoting that they started talking their own language.

The search of the lyrical hero's ways of self-identification and self-expression are carried out in this wreath of sonnets in various directions and take many different forms: autonominations and self-characteristics; designing the art of space and time; the motive of vagrancy and search of the "own" and "native"; approval of uniqueness and exclusiveness of "I" and refusal of individual life, merge to the nature; denial of a word, leaving in silence and a new type of creativity - "laying" a wreath. The plurality, not integrity, discretization of identifications, caused the principles of cyclic communication of sonnets, the characteristics of R. Bukharayev's creativity. The consecutive "chained" connection of isomorphic strophe structures is combined with the concentric principle of development of a subject that gave the grounds to critics to call sonnet cyclic units by R. Bukharayev not the "wreaths", but "clusters" of sonnets [16].

The third sonnet cycle, A Wreath of Wild-Growing Sonnets, reflects the experience of self-determination of the lyrical hero in foreign culture. The sonnets are saturated with Hungarian "culture". The epigraphs by Attila József (1905-1937) and Dezso Kosztolányi (1885-1936) works are a prologue to the cycle; the other Hungarian poets - Ady Endre

1 Deixis - a definition with the nature of "the external index gesture directed to the called subject" [15. P. 175]. 
(1877-1919) and Csáth Géza (1887/1888-1919) - are also mentioned in the text, the Hungarian cities of Karcag, Budapest, Calvin Square, Kostolany, gardens, the Danube River are also described. The lyrical hero of R. Bukharayev tries to find his place in this world. Search of "his own" in "foreign" defines the figurative and subjective structures of a cycle.

Familiarizing with another national culture and traditions begins with contemplation of an autumn garden, which is alien and differentfor the lyrical hero. The self-sufficiency of a garden, its complete, closed life with its daily rhythms is emphasizedin the poem: "Look soberly - an autumn garden is around / that lived without you so far, it's rich, / it blossomed and it faded, dissolved its buds, / it sinned and it repented from year to year..." [1. P. 330]. Therefore, the question, filled with the tragic foreboding of the nonparticipation in this life ("Does the fruit shines for you / inside the crimson sprinkled krone?" [1. P. 330]), is replaced by the ascertaining: "Here wind plays and enchants light: / they areharsh due to my strangeness...” [1. P. 330].

The hero of the sonnet cycle perceives the world of foreign culture in subjective forms. The garden, the fall, the trees, the wind, the stars, the inflorescences, the branches, the bird - all these become independent characters. The active role in existential drama belongs to the fall - the time of immanent harvesting and withering of Nature. The autumn state of World is transformed into the existential and substantional figurativeness: "... and Fall, not laying its arms on a grass, / floats through a garden in the beams of its crown" [1. P. 331]. The subjective prospect of its actions is presentin the work: "The fall knits lace transparently, / goes thoughthe garden as if through a sonnet..." [1. P. 331]. The fall reaches for "others" and gives them the fruits: "... for József - a nettle, / for Kostolany - a rose of beer-color, / for Ady - the dahlias and grass..." [1. P. 331]. But it knows nothing about the lyrical hero ("Oh, fall, what do you know of me?" [1. P. 330]), and the hero is bewitched by its clear sky, sleepy stars, dew in foliage, and the garden, "where everything lives other destiny" [1. P. 332]. The spring, as well as the fall, is indifferent to the lyrical subject: "There is a honeysuckle, and here is a lilac in bloom, / here is willow branches that were lifted up by wind... / What does it have to do with I?" [1. P. 335].

The feeling of the irrelevance and uselessness to the Fall and the Spring turns into the total alienation from life in general: "Life with easy wave / banished me to emptiness forever" [1. P. 335]. Identifying the Life as a woman, R. Bukharayev gives it an "allfoundness" and "all-liveliness" as an active position. The difficult correlations are established betweenthe female life and the hero of the sonnet cycle: "... and life in a feminine way will lie or not" [1. P. 333]. The need for a family relations with Life ("... and I reach for it as the child to mother' [1. P. 335]) is turned into the emptiness and inevitable oblivion: "Everything is designated, off-base - remains the fear that life will forget me hurriedly..." [1. P. 335]. Oblivion performs destructive negative function, destroying time and performing a mythological metamorphosis: "Life leaves, leaves without joking, / having again turned the man into the child" [1. P. 335].

The special form of alienation is the alienation from one's personality, which is characteristic of self-consciousness of "I" through the independence of the "soul" from the "flesh" ("Do behave yourself, my soul, you are too young / flesh did not cease to writhe yet..." [1. P. 329]), its materialization and substantivity. From there appeals are 
turned to soul: "Hurry behind it (after Fall - V.A., L.Y.), soul, behind a tree, / on Logodi, on the small street lit by dawn!" [1. P. 331]. R. Bukharayev carries on the traditions of G.Tuqay and other Tatar poets of the beginning of the 20th century, allocating soul with independent life and ability to influencethe events of human life (see: [18. P. 80-82]). In $A$ Wreath of Wild-Growing Sonnets this trend is shown to a limit, up to the opposition of soul to the body ("Soul and flesh are at enmity from time to time..." [1. P. 335]) and its separations: soul can be carried "over the borders" "even to Sydney" [1. P. 336]. The deeply personal existence of the soul is not described, but defined by the psychoemotional states endured by it, which are also given the subjective rank. Melancholy turns into a bat. "Melancholy is a bat / that rushes about, peeps around, and passes all obstacles..." [1. P. 331]. "Pain", the first wordlearned in Hungarian, "ascends light and grass" [1. P. 332] "is distributed in breadth" [1. P. 335]. "Soul" is unbearable, and the lyrical hero presents to it the sonnet-savage "instead of flowers" [1. P. 336]. The images bearing semantics of pain reveal the crisis state of "soul" - the equivalent to the special measurements between life and a non-existence.

The hero of the sonnet cycle is released not only from himself and from the substantive reality of life, but also from daily communication, from all full-fledged communicative situations, therefore "Budapest is like a desert" [1. P. 333]; the meeting with Csáth Géza is also not pleasant: "Again coffee and liqueur rose in price, / it is not greed for pennies, the conversation / under heaven locked is a pity, vague" [1. P. 334]. Foreign culture appears in the personified image: "Madams, with a straw in a mouth" [1. P. 333]. The fog, which symbolizes the illusiveness, irreality of life, indistinguished ability of all phenomena, consciousness disintegration, becomes its indispensable attribute: "From there, where Danube is seen slightly better / and fog lies on the squares in strips; / the passerby I did not recognize; however, we also does not recognize ourselves in the fogs of days. / Ah, madam, your charms... are foggy" [1. P. 334]. The lyrical hero feels a threat of disappearance, dispersion and dissociation sharply in this other world: "As the ghost, in devout melancholy, / I stick out with the guilty head here..." [1. P. 332]. The discourse of uncertainty and non-identity corresponds also with the existential state of the "farewells with the stepfather's words": "My farewell with the stepfather's words / grows and gets stronger as a wood trunk / without name; to be seduced with names / is naive if in the beginning there was a Verb" [1. P. 336].

Way of finding oneself and, at the same time, overcoming the border between "one's own" and "another", the dissolution of "another" in "one's own" - understanding of it turns into the language study for the lyrical hero of R. Bukharayev: "Here (I see emptiness for strangers), / I, without understanding anything yet, / have comprehended the simplicity of Hungarian language" [1. P. 333]. The Hungarian for the lyrical hero is "a music, sliding easily into the forbidden" [1. P. 337]. The nature sounds become the communication medium along with language: "And life is simple - whatever blood to feed / verse, the wood and a dale will answer, / and music will continue between branches / a yellow bird or Eol” [1. P. 336].

Knowledge of the foreign language performs a substitution function: "In world order a worm is equal to a rose; / I write, hiding in this metamorphosis / the native Tatar speech numbness" [1. P. 336]. The elements of the mythological metamorphoses - identifying melancholy with a bat, pain with a word, a worm with a rose - extend also to the languages. 
This stream of metamorphoses fixes the moment of transition and, at the same time, symbolically holds both limits - the native and someone else's language, sounds of the nature and music of language, lines of the sonnet and flowers in a bouquet.The nature and art are not the isolated phenomena, but the syncretic unity.

In this sonnet cycle, as well as in previous ones, creativity becomes the highest form of self-determination in foreign culture. The art situation in A Wreath of Wild-Growing Sonnetsis created when the beginning of "a native verse born in the foreign land" is shown [1. P. 333]. The definition of the sonnet - "a wild sonnet in bloom, / the sour spot of a garden and the other summer" [1. P. 336], "a wild sonnet, your root is superficial..." enters into a circle of the natural phenomena, such as the trees speaking "good old Magyar language" [1. P. 332], wind with its monotonous swirls, a thread of the stars shining in the clear sky, a ringing of wet inflorescences, etc. Laws of its birth have natural character: "But the branch got free from the sleeping buds, / and in this hope I am at the end of the resources, / all right, here is the sonnet - a wild sonnet in bloom..." [1. P. 336].

Another series identifying nominations and appeals emphasizes their emotionalpsychological nature in verses and reveals the process of transforming some phenomenon into another: "The Hungarian wind blows through me, / sifting pain in passing day - / it ascends light and grass, / not therefore in this silence / you break off my soul with pain, / a wild sonnet - what do I do with you?" [1. P. 332]; “... the verse (what more than a miracle) / will increase everyday life vanity" [1. P. 333]; “... in the verse the soul is above a body" [1. P. 334]; "What is a verse? The picture in a bright frame, / an enthusiastic scene in the boring drama, / and all my diligence not for the future" [1. P. 337]. Characteristic of verses contains the autoreflective trend enhancing tragic and ironical tone of a sonnet cycle: "What do I create from the borrowed language / my duel - my homeless diligence, / why do I play simplicity again?" [1. P. 337].

The connection in a wreath of "wild-growing sonnets" of two intensions - natural spontaneous and spiritual human - removes the border between them, allocating the creative process with mythological lines and finding in it complementarity of the mutually exclusive beginnings, "one's own" and "another", the nature and the person, silence and a word, light and darkness, etc. This context also neutralizes the opposition arising between the subjects of creativity - "the Magyar eagle" and "the Tatarrooster": "Madam, who there in the darkness screams, / the Magyar eagle or the Tatar rooster?" [1. P. 338]. Figurative and semantic connection, which is established between the phenomena belonging to different ranks of conceptualization of reality, prepares transition of the lyrical hero, who is self-critically estimating himself, and his efforts for positive acceptance of the world: "Where we are absent, I will find joy. / There will be happiness in the foreign land too" [1. P. 338]. Therefore, the catharsis (finding the "one's own" in "another" and tragic eradication of the foreign "I"), leads to the world of another culture. The idea of the movement and spiritual "way" is expressed in the breaking up with this stage of life: "Farewell, my Budapest, - in foggy gardens, / farewell, in the damned intuitions, / I thank you for the feelings and words, / for the fact that Ireached the end of my resources, / having caught sight that in the last line / flickering, a cherry is slightly alive" [1. P. 338]. Here again lies the leitmotif of the whole cycle - "the vegetative code" is implemented (rapprochement of lines with leaves, the sonnets with plants), characterizing the culmination point of creative experience of the lyrical hero. 


\section{Conclusion}

The wreath of sonnets attracts R. Bukharayev's attention as esthetically distinguished and sublime form of creativity with inexhaustible art potential. But the poet not only reproduces the structural and substantial features, characteristic of it, but also goes to new understanding of the ways of the organization among the poetic thoughts. The art integrity of this genre and strophe system is created in R. Bukharayev's creativity, not only by the "chained" design of a wreath connecting the end and the beginning of all cyclic context in general, but also the concentric development of the main subject. The intense thoughts about a language as the greatest national, historical, and cultural value are projected on the different spheres of life of the personality and are revealed in the different aspects that gives conceptuality to the main subject of each wreath and the art and esthetic importance.

The subject structure of the sonnet cycles by R. Bukharayev, including AWreath of Wild - Growing Sonnets, forms a union of two prospects and two intensions corresponding to them through the lyrical hero - from the supersubjects of special type (in this case Falls, female Lives, Madam Foreign Lands, etc.), taking a position of easily finding extra vital activity in relation to the world of "I" - from another. Dialogue of "I" with this point of view performsthe structure-forming function, forming art and esthetic integrity of this genre and strophe system and defining ways of self-identification and self-expression of the hero of a sonnet cycle.

\section{References}

1. Bukharayev, R.R. 2011. Selected Works: Book of Verses. Kazan: Magarif - Wakyt. 415 p. Print.

2. Bukharayev, R. 2001. Infinite Train: Chosen Verses and Poems. Kazan: Magarif. 319 p. Print.

3. Bondarenko, V.A. 2011. Slavic Stock to a Turkic Savage. Kazan: Magarif - Wakyt: 373-389. Print.

4. Ibragimov, M.I. 2016. "Chronotope and Identity (on the example of a cycle of verses of Ravil Bukharayev "The Kazan Snow")". Literature at school. 6: 41-43. Print.

5. Bukharayeva, L. Hungarian Measurement of Creativity of Ravil Bukharayev, Web. //http://kazanjournal.ru/pages/item/5129-buharaev (Date of the address: 01.06.2018).

6. Lozhkova, A.V. 2012. "Sonnet as a Lyric Genre". Ural philological journal. 6: 5-18. Print.

7. Ostankovich, A.V. 2008. "Genre Specifics, Principles and Regularities of Cyclic Communication of Sonnets". Journal of the Stavropol State University. 5: 39-44. Print.

8. Talysbayeva, Zh.Zh. 2015. "About the Nature of Transformations of a Wreath of Sonnets in Poetry of the 20-21st centuries". The Siberian philological journal. 1: 133-139. Print.

9. Tlostanova, M.V. 2004. Post-Soviet Literature and Esthetics of a Transculture. To Live Never, to Write from Nowhere. Moscow: URRS. 2004. 416 p. Print.

10. Bakhtikireeva, U.M. 2005. Art Bilingual and Features of the Russian Art Text of the Writer Bilingual. ADD philol. sciences. Moscow. 35 p. Print.

11. Bhabha, H. 1994. The Location of Culture. New York. 408 p. Print.

12. Berry, E., and M. Epstein. 1999. Transcultural Experiments: Russian and American Models of Creative Communication. New York: St. Martin's Press, 340 p. Print.

13. Korman, B.O. 2006. Chosen Works. Theory of Literature. Izhevsk: Institute of computer researches. 552 p. Print.

14. Broytman, S.N. 2001. Historical Poetics. Study Guide. Moscow: Russian State Humanitarian University. 320 p. Print.

15. Khan, A. 2001. Poetic Universe. Analysis of the Poem of B. Pasternak "Definition of poetry": Preliminary Results to the Analysis of the Cycle "Engagement in Philosophy". Studia Russica. 19: 169-188. Print. 
16. Yarantsev, V. “...We will make out the friend in the light of God”. Web. //http://www.sibogni.ru/ content/buharaev-ravil-kazanskie-snega-stihi-kazan-magarif-2004 (Date of the address: 01.06.2018).

(C) Amineva V.R., Yuzmukhametova L.N., 2018

This work is licensed under a Creative Commons Attribution 4.0 International License

Article history:

Received: 27.10 .2018

Accepted: 29.12.2018

Moderator: V.P. Sinyachkin

Conflict of interests: none

\title{
For citation:
}

Amineva, V.R., and L.N. Yuzmukhametova. 2019. "Self-Identification of Ravil Bukharayev's Lyrical Subject (as seen in A Wreath of Wild-Growing Sonnets)". Polylinguality and Transcultural Practices, 16 (1), 63-72. DOI 10.22363/2618-897X-2019-16-1-63-72

\section{Remark:}

The text of the article was submitted as a report on IV International Conference "Bi-, Poly-, Translingualism and Language Education”, Moscow, December 7-8, 2018.

\section{Bio Notes:}

Venera R. Amineva is a Doctor of Philology, Associate Professor, Associate professor of the Russian and Foreign Literature Department of "Kazan (Volga) federal university". Leading researcher at A.M. Gorky Institute of World Literature of the Russian Academy of Sciences. E-mail: amineva1000@list.ru

ORCID: http://orcid.org/0000-0003-4016-2242

SPIN: https://elibrary.ru/author_items.asp?authorid $=627370$

Landysh N. Yuzmukhametova is a Candidate of Philology, Associate professor of the Department of Foreign languages for the Social and Humanitarian Direction at the Institute of the International Relations of "Kazan (Volga) federal university”. E-mail: land_yz@mail.ru

ORCID: http://orcid.org/0000-0001-9385-7684

SPIN: https://elibrary.ru/author_items.asp?authorid=796942

\section{Пути самоидентификации лирического субъекта Р. Бухараева (на материале цикла «Венок дикорастущих сонетов»)}

\author{
В.Р. Аминева, Л.Н. Юзмухаметова
}

Казанский (Приволжский) федеральный университет Республика Татарстан, 420008, Казань, ул. Кремлевская, 18

На материале стихотворного цикла Р. Бухараева «Венок дикорастущих сонетов» рассматриваются особенности функционирования данной жанрово-строфической формы в современной русскоязычной поэзии. Установлено, что субъектная архитектоника этого сонетного 
цикла формируется отношениями лирического героя и сверхсубъектов особого типа - персонифицированных образов чужой культуры. В статье описываются основные способы преодоления границы между «своим» и «чужим»: рутинное/креативное общение на венгерском языке, выполняющее заместительную функцию. Творчество наделяется мифологическими чертами и обнаруживает взаимно однозначные соответствия природы и человека, «своего» и «чужого», молчания и слова, строчек сонета и цветов в букете.

Ключевые слова: русскоязычная литература, гибридная идентичность, «свое», «чужое», поэтика жанра, субъектная архитектоника

\section{История статьи:}

Дата поступления в редакцию: 27.10.2018

Дата принятия к печати: 29.12.2018

Модератор: В.П. Синячкин

\section{Конфликт интересов: отсутствует}

\section{Для цитирования:}

Аминева В.Р., Юзмухаметова Л.Н. Пути самоидентификации лирического субъекта Р. Бухараева (на материале цикла «Венок дикорастущих сонетов») // Полилингвиальность и транскультурные практики. 2019. Т. 16. № 1. C. 63-72. DOI 10.22363/2618-897X-2019-16$1-63-72$

\section{Примечание:}

Статья была представлена в качестве доклада на IV Международной конференции под эгидой МАПРЯЛ «Би-, поли-, транслингвизм и языковое образование», Москва, 7-8 декабря 2018.

\section{Сведения об авторах:}

Аминева Венера Рудалевна - доктор филологических наук, доцент, доцент кафедры русской и зарубежной литературы Казанского (Приволжского) федерального университета, ведущий научный сотрудник Институт мировой литературы им. М. Горького РАН. E-mail: amineva1000@list.ru

ORCID: http://orcid.org/0000-0003-4016-2242

SPIN: https://elibrary.ru/author_items.asp?authorid $=627370$

Юзмухаметова Ландыш Нургаяновна - кандидат филологических наук, доцент кафедры иностранных языков социально-гуманитарного направления Института международных отношений Казанского (Приволжского) федерального университета. E-mail: land_yz@ mail.ru

ORCID: http://orcid.org/0000-0001-9385-7684

SPIN: https://elibrary.ru/author_items.asp?authorid $=796942$ 